\title{
1. Internships: A policy and regulatory challenge
}

\author{
Andrew Stewart, Rosemary Owens, Niall \\ O'Higgins and Anne Hewitt
}

There is no single body of experts, no famed multinational corporation, no particular institution or government that is pushing the relentless global expansion of internships - a process occurring so rapidly, and at the instigation of so many different actors, that its contours seem almost impossible to gauge. The dynamics vary substantially from country to country, with particular labor laws, different industries and specific values surrounding work all coming into play, but the overall direction is clear: internships are pushing into the workplaces of middle- and high-income nations the world over. What took four decades to materialize in the U.S. has rapidly become a global fact of

life: internships are at once a significant source of cheap, flexible white-collar labor and a major steppingstone to affluence and professional success. They grant access to those who can afford them, and block further progress for those who cannot. ${ }^{1}$

\section{$1.1 \quad$ INTRODUCTION}

Over the course of the decade since Ross Perlin wrote the words above, little has changed to dispute his analysis. If anything, internships have become even more firmly entrenched in the transition from education to work. However, this phenomenon is still not attracting the attention it deserves. To help remedy that, this volume, the first of its kind, brings together experts from around the world in labour law, employment relations and labour economics to explain what we know about the use and value of internships, and to discuss how they are or should be regulated.

In this opening chapter, we offer some preliminary explanations for the growth of internships, highlight some of the ways in which both scholars and policy-makers have sought to analyse and respond to that development, explain how the rest of the volume is structured and briefly summarize the contributions in it. We conclude by saying something about the impact that the

1 Ross Perlin, Intern Nation: How to Earn Nothing and Learn Little in the Brave New Economy (rev edn, Verso Books 2012) 185-6. 
COVID-19 pandemic has had so far on internships and what it might mean for their use in the future.

Before going on, it is necessary to say what we mean by the term 'internships'. More is written both below and in Chapter 2 of this volume about the different types of arrangement that can potentially attract this label. For now it suffices to say that, as the editors of this volume, we take an internship (or a 'traineeship', as it is sometimes called in Europe) to be any arrangement for the performance of work within a business or organization which is primarily intended to provide experience, skills and/or contacts that will help the worker obtain employment or other work opportunities in the future. As we use the term, it does not matter whether the internship is undertaken during, after or as part of a formal scheme of education, training or government assistance. We also distinguish an internship from an apprenticeship, on the basis that the latter seeks in a more structured (if not always formal) way to provide all the skills needed to practise a particular trade or profession.

Having said that, we need to express the caution that this terminology is far from exact. It is not the subject of any generally accepted definitions, whether for legal or other purposes. Even within the pages of this volume, the terms internship and intern (or traineeship and trainee) may be used in ways that reflect different traditions or usages within a particular country, region or language. The same is true of apprenticeship and apprentice, as the International Labour Organization (ILO) has acknowledged. ${ }^{2}$ Nevertheless, we have tried as far as possible to encourage our contributors either to focus on internships in the general sense described above or, where they are concerned only with particular types of internship, to be clear about that.

\subsection{SEPARATING TRAINING FROM PAID EMPLOYMENT}

There is nothing new in the idea of combining work and training. The traditional model of apprenticeship has always been premised on the idea of learning a particular trade or craft, while performing work to practise what has been learnt and to hone the skills involved. The modern form of apprenticeship that now predominates in higher-income countries typically requires time release from work to attend classes at an educational institution. However, on-the-job instruction still remains an integral element of these schemes, as it does in the more informal arrangements still found in many developing economies. In many professions too, whether called apprenticeships or not, licensing

2 See ILO, A Framework for Quality Apprenticeships (International Labour Office 2019) 5-7, 15-16. 
or accreditation schemes often require a period of time to be spent working under the supervision of experienced practitioners. Beyond those more formal requirements, it has long been a feature of entry-level jobs that an initial period will be spent 'learning the ropes', while adjusting both to the type of work involved and the demands of the employing organization.

What has been striking in recent decades, especially but not solely in developed economies, has been the steady decoupling of training from paid employment. One reason for that has been the growth of formal education programmes, whether in universities or technical colleges. Many of the placements or 'practica' required to practise a particular trade or profession are now undertaken as an element of these programmes - and because of that, they are often unpaid or compensated at a rate below that which an entry-level job might otherwise provide. Even where vocational or professional requirements do not make a work placement compulsory, it is now common for educational programmes to require or allow students to undertake some form of work experience as a part of their studies. For example, a student might complete a supervised and formally assessed research project both for credit in their course and (potentially) for the benefit of the agency or organization for which the project has been undertaken.

Governments too have assumed a role in facilitating or even requiring work experience, not least as part of active labour-market programmes (ALMPs) designed to assist job seekers - in particular, the long-term unemployed or those identified as being in some way disadvantaged in seeking to enter or re-enter the labour market.

In addition to hosting students or job seekers undertaking work experience as part of formal education or training programmes, many businesses, non-profit organizations and government agencies have developed internship schemes of their own. These can sometimes involve paid employment, but they are just as likely to be characterized as a form of unpaid training. Some are highly structured, while others operate less systematically. They can allow participants to gain work experience in many different ways, whether by performing actual or mock assignments, or simply shadowing more experienced workers and observing what they do. In some internships, basic or even menial tasks may be required, sometimes for the personal benefit of key employees or managers rather than the organization for which they work. In such cases, the perceived value of the internship may lie as much in what they add to the intern's curriculum vitae $(\mathrm{CV})$ or résumé, or the contacts they promise to provide, as in the acquisition of any particular work-related skills or knowledge. 
There appear to be many drivers for the growth in the prevalence of this form of work-based learning. ${ }^{3}$ For example, job seekers may be eager to take every possible opportunity to improve their chances of employment, especially in fields where there is an oversupply of otherwise qualified applicants. Indeed, many are now willing to pay money to internship brokers for the privilege of doing unpaid work in the profession or industry of their choice.

Many businesses or organizations have also come to recognize the value to them of internships, thus increasing the number of such positions on offer. Taking on interns may, for example, be a useful form of pre-employment screening. More problematically, however, unpaid (or low-paid) internships can also be used to obtain productive work that would otherwise be done by paid employees, thus reducing labour costs. The more that some employers do this, the greater the likelihood that others will follow suit to remain competitive.

The rise of internships also needs to be understood in the context of a changed approach to skills development. The pressure on modern businesses to deliver returns to shareholders, and the lack of predictability in what are often now global markets, militate against long-term investment in training. The in-house training that was once part of many entry-level jobs is now far less evident, in effect shifting the costs of training from the firm to the worker - or the state, to the extent it funds the worker's education and training.

Another driver has been the embrace by higher education institutions of what is often now termed 'work-integrated (or experiential) learning'. This often flows from a pedagogical belief that there are certain types of skills or knowledge that are best acquired through trial and practice rather than classroom-based learning. However, it may also reflect an acceptance of the increasingly common demand for graduates who are 'work ready'. Governments too have been important supporters of the concept of work-based learning, especially in higher education or the types of ALMP arrangement mentioned earlier.

\subsection{ANALYSING AND RESPONDING TO THE GROWTH IN INTERNSHIPS}

For many years, research and writing on internships was most commonly found in educational studies on the value and effectiveness of particular forms

See Rosemary Owens and Andrew Stewart, 'Regulating for Decent Work Experience: Meeting the Challenge of the Rise of the Intern' (2016) 155 ILR 679, $682-3$, from which some of the text that follows is taken. 
of placement or work experience. ${ }^{4}$ Attention to regulatory issues was less common. ${ }^{5}$ However, that has changed over the past decade. One influential contribution was Ross Perlin's book Intern Nation, quoted at the beginning of this chapter. ${ }^{6}$ He drew attention to the growth of internships both in the USA and globally, highlighting the complexity of the web of interests - employers, parents, educational institutions, government agencies and interns themselves - invested in the phenomenon. Significantly, he characterized internships as a form of contingent or 'non-standard' work, ${ }^{7}$ a point also made by Guy Standing in The Precariat. ${ }^{8}$ The vulnerability of interns to exploitation has been reiterated in subsequent analyses. ${ }^{9}$ The same is true for Perlin's emphasis on the way in which requirements to undertake unpaid or low-paid internships may impose or strengthen barriers to entry to certain professions for those from less privileged backgrounds. ${ }^{10}$

Regulators and policy-makers have also turned their attention to this topic, at least in some parts of the world. Their efforts have in turn led to an upsurge in commentary from scholars in labour law and employment relations, not least some of the contributors to this volume. Argentina, Brazil and France were some of the earliest countries to pass laws specifically regulating internships, ${ }^{11}$ while others have moved either to bring internships within the coverage of particular forms of labour regulation, or to exclude them. ${ }^{12}$ In the

4 See eg the studies summarized in Gisela Sanahuja Vélez and Gabriela Ribes Giner, 'Effects of Business Internships on Students, Employers, and Higher Education Institutions: A Systematic Review' (2015) 52 J Employ Couns 121.

5 For exceptions, see eg David L Gregory, 'The Problematic Employment Dynamic of Student Internships' (1998) 12 NDJLEPP 227; David C Yamada, 'The Employment Law Rights of Student Interns' (2002) 35 Conn L Rev 215.

6 Perlin (n 1).

7 Ibid 36-41, 197-202.

8 Guy Standing, The Precariat: The New Dangerous Class (Bloomsbury Academic 2011) $16,75-6$.

9 See eg Sabina Siebert and Fiona Wilson, 'All Work and No Pay: Consequences of Unpaid Work in the Creative Industries' (2013) 27 Work, Empl \& Soc 711; Annika Rosin, 'Precariousness of Trainees Working in the Framework of a Traineeship Agreement' (2016) 32 IJCLLIR 131; Owens and Stewart (n 3).

10 See eg Carl Cullinane and Rebecca Montacute, Pay As You Go? Internship Pay, Quality and Access in the Graduate Jobs Market (Sutton Trust 2018).

11 Creacion del Sistema de Pasantias Educativas en el Marco del Sistema Educativo Nacional Ley No 26427 (Argentina); Lei do Estágio, No 11788 of 2008 (Brazil); Loi no 2011-893 pour le Développement de l'Alternance et de la Sécurisation des Parcours Professionnels (France).

12 See the various examples provided in Andrew Stewart, Rosemary Owens, Anne Hewitt and Irene Nikoloudakis, 'The Regulation of Internships: A Comparative Study' (2018) International Labour Office Employment Policy Department Working Paper No 240, which surveys the law in 13 different countries: Argentina, Australia, Brazil, 
USA, the Wage and Hour Division of the Department of Labor issued a fact sheet in 2010 that sought to provide guidance to businesses on whether interns should be considered employees. ${ }^{13}$ This prompted a number of private test cases by unpaid interns to establish their entitlement to minimum wages under the Fair Labor Standards Act 1938, although these have not met with complete success. ${ }^{14}$ By contrast, Australia's Fair Work Ombudsman has successfully brought proceedings against a number of firms for underpaying interns, as part of an active strategy not just to improve understanding of the legal position, but to develop 'best practice' approaches that can improve the quality of work experience programmes and reduce the misuse or exploitation of young job seekers. ${ }^{15}$ In other countries, greater emphasis has been placed on the use of 'soft law', such as codes of practice, to influence the use and content of internships in both government and non-government organizations. ${ }^{16}$

In 2014, the Council of the European Union (EU) took the significant step of formulating guidelines for its member states on how to improve the quality of what it chose to call 'traineeships'. ${ }^{17}$ The Quality Framework for Traineeships seeks, among other things, to increase the transparency of internship conditions, such as through the requirement of a formal internship agreement, although it leaves unresolved the question of whether, and if so to what extent, interns are or should be protected by general labour and social laws. ${ }^{18}$

Canada, China, France, Germany, Japan, Romania, South Africa, the UK, the USA and Zimbabwe. For a thorough (though now slightly dated) review of regulation in the European Union, see Kari P Hadjivassiliou, Emanuela Carta, Tom Higgins, Catherine Rickard,

Suzanne Ter-Minassian, Flavia Pesce and others, Study on a Comprehensive Overview on Traineeship Arrangements in Member States: Final Synthesis Report (European Union 2012).

13 Wage and Hour Division, US Department of Labor, 'Fact Sheet \#71: Internship Programs under the Fair Labor Standards Act' (US Department of Labor 2010). See Natalie Bacon, 'Unpaid Internships: The History, Policy, and Future Implications of "Fact Sheet \#71"” (2011) 6 OSEBLJ 67.

14 See eg Glatt v Fox Searchlight Pictures, Inc 811 F 3d 528 (2016). For further discussion of the position in the USA, see James Brudney, Chapter 10 in this volume.

15 See Stewart and others (n 12) 31-2, 41-2.

16 Ibid 43-4, discussing among other things the Common Best Practice Code for High-Quality Internships developed in the UK by the Gateways to the Professions Collaborative Forum.

17 Council of the EU, Council Recommendation of 10 March 2014 on a Quality Framework for Traineeships [2014] OJ C88/1.

18 As to the impact of the framework, see eg Lukasz Sienkiewicz, Traineeships under the Youth Guarantee: Experience from the Ground (European Commission 2018). 
For its part, the ILO has recognized both the role that internships can play in helping to obtain decent work and the risk that they may be used by organizations to obtain cheap labour or replace existing workers. ${ }^{19}$ At the time of writing, it is seeking feedback from its member states on the development of new international labour standards on apprenticeships and other forms of work-based learning, including internships. ${ }^{20}$ More is said about these initiatives, as well as the applicability of existing international labour standards, in Chapter 20 of this volume.

\subsection{THE CONTRIBUTIONS IN THIS VOLUME}

In Chapter 2, Andrew Stewart explains how internships can be defined and distinguished from other forms of work-based learning and explores what is known about their prevalence. The chapter concludes by highlighting four persistent policy concerns, some already mentioned in this chapter: whether internships deliver quality training; whether they do provide the promised bridge from education to paid work; whether unpaid or low-paid internships impede social mobility; and whether these arrangements may be displacing paid employment and undermining labour standards.

The second and third of those policy issues are taken up in Part II of this volume, which presents new data and insights on the question of whether and to what extent internships have a positive effect on employability. In Chapter 3, Niall O'Higgins and Luis Pinedo Caro demonstrate on the basis of a literature review and further analysis that paid open-market internships are better than unpaid internships for young people's post-internship labour-market outcomes. The obvious follow-up question is 'Why?' Their answer lies not in the payment of interns per se, but in the fact that paid internships are, on average, of higher quality than those that are unpaid. Paid internships tend to be more structured and formalized, and consequently are characterized by elements which increase the likelihood that young interns gain skills and competencies of lasting worth.

These conclusions find resonance in Chapter 4 in which Charikleia Tzanakou, Luca Cattani, Daria Luchinskaya and Giulio Pedrini analyse the effects on graduate early labour-market experiences of internships undertaken as part of higher education, comparing the case of the UK with Italy. They find that these internships have a positive, albeit limited, effect on the early labour-market experiences of university graduates in both countries, with

19 See eg ILO, 'The Youth Employment Crisis: A Call for Action' (Resolution and Conclusions of the 101 st Session of the International Labour Conference 2012) para 24.

20 ILO, A Framework (n 2). 
better internship-related outcomes in the UK. Their analysis also throws light on some more nuanced issues. As with the previous chapter, they find that paid internships are associated with better subsequent labour-market outcomes. They also highlight, however, the importance of definitional questions, which impede precise comparisons across (but also within) countries on this issue. Their results indicate a signalling role for internships, although they caution that, should internships become compulsory, this role will be diluted.

A related issue is taken up in Chapter 5, in which Paula McDonald, Andrew Stewart and Damian Oliver note that as unpaid work experience becomes more common so it must logically be harder for participants to acquire a competitive advantage in the labour market. They note also that, as other contributions to Part II suggest, the real gains in employability may come from high-quality experiences. If so, it becomes even more important to ensure that social background does not limit access to the better types of internship.

Wil Hunt and Charikleia Tzanakou take the argument one step further in Chapter 6. Their analysis of internships among creative and mass communications students in the UK confirms that paid internships are associated with increased chances of subsequently obtaining creative employment and with a significant wage premium for those who do find jobs. Unpaid internships not only do not provide any boost to the graduates' employment prospects, but those students who undertake them subsequently earn less than those who do no internship at all. Different approaches to the regulation of internships are reviewed and, while no particular regulatory approach is inherently superior to the others, details matter. In particular, whichever approach is taken needs to be based on a clear definition of the boundaries between work placements while in education, open-market internships and genuine volunteering.

Part III turns to the question of state regulation and takes a more in-depth look at how internships are being treated in six different countries, whether under existing or new laws. The regulatory regime of Germany, as outlined by Bernd Waas in Chapter 7, provides a comparatively strong example of the increasing application of labour law to internships or traineeships. However, with a framework dependent upon various different definitional foundations, its strength remains susceptible to interpretive challenges and the problem of sham employment relationships. The segmented approach to internships presented by the German model may also risk exacerbating these weaknesses. In Chapter 8, Mahlatse Innocent Maake-Malatji examines the role of internships and their regulation in providing a pathway from education to employment for black graduates in South Africa. In so doing she places the issue within the wider historical context of apartheid and its ongoing economic and social legacies, including unemployment, poverty and inequality. Her argument suggests that if the centrality of vocational skills training and development to entering, participating and remaining in a changed world of work is recognized, as it was 
by the ILO's Global Commission on the Future of Work, ${ }^{21}$ then to be effective in practice the regulation of internships must be embedded in strategies that break the vicious cycle whereby internships simply become a path to further unemployment, poverty and inequality.

In Chapter 9 Jenny Julén Votinius and Mia Rönnmar explore various forms of internships and apprenticeships within the Swedish labour law and industrial relations system. These non-traditional work relationships have been encouraged in Sweden to assist young people, and more recently immigrants and the long-term unemployed, to enter the job market. However, active and autonomous social partners, the determination of wages through collective bargaining and a presumption that the costs of labour-market inclusion should be borne by the state have, to date, minimized the potential risks of apprenticeships and internships to individuals and more broadly at the societal level.

In a forensic examination of the regulation of internships in the USA, Chapter 10 analyses the changes in judicial interpretation of the major federal labour statute in this area over the past eight decades. James Brudney argues that the current interpretive approach is in tension with the statutory text, legislative history and long-standing application of the statute by the administration. The replacement of strict criteria by increased judicial discretion in more recent decisions has diminished labour protections for interns, just at a time when empirical evidence and arguments provide little policy basis for this approach.

In Chapter 11, Rosemary Owens uses the vehicle of the common law of Australia and the UK to assess what the regulation of internships can tell us about the scope and limits of labour law. In these and most other legal systems, the employment relationship is the touchstone for the protection of labour law, and is determined by a multi-factor test usually applied to distinguish independent contractors and employees. The current world of work presents many challenges, including from new and informal forms of work, which can undermine its role in this regard. When labour law confronts the intersection of work and education, some legal systems deploy a test determining the (primary) purpose of an internship relationship. This often results in a regulatory separation of work from education or welfare, and a failure to protect those undertaking internships or traineeships. The chapter argues that what is needed for labour law to fulfil its purpose is a normative approach which both acknowledges human rights standards that must apply to all regardless of their employment status and, in all other circumstances involving work, respects the

${ }^{21}$ ILO, Work for a Brighter Future: Global Commission on the Future of Work (ILO 2019), https://www.ilo.org/wcmsp5/groups/public/---dgreports/---cabinet/ documents/publication/wcms_662410.pdf, accessed 30 March 2021. 
fundamental principles that labour is not a commodity and that there should be decent work for all.

In Part IV, our contributors consider some of the regulatory issues that arise in the specific contexts of education and social welfare. Joanna Howe examines in Chapter 12 the emerging regulatory landscape and the regulatory opportunities and challenges created when students travel abroad to complete an educational internship. Universities have been increasingly promoting these opportunities to students, and although the COVID-19 travel restrictions have temporarily halted this growth, it seems likely to resume as restrictions ease. The chapter concludes that educational internships abroad are being promoted in the absence of policies and processes to respond to legal issues that arise as a consequence of labour and migration law, that students are often inadequately prepared for their overseas experience, and that measures to assess safety and other workplace risks and dangers, and processes for responding when undesirable situations arise, are rudimentary or non-existent.

In Chapter 13 Anne Hewitt interrogates the common assumption that the involvement of universities ensures that internships completed as a part of higher education are better regulated and of higher quality than other internships. The chapter considers the educationally focused regulation of internships in Australia, England and France, and critically examines the regulatory role played by Australian universities, in order to determine whether the educational regulation is being effectively implemented. Her conclusion is that Australian universities are failing to ensure that internships are consistently compliant with educational regulation, a conclusion which may sow seeds of doubt about the effectiveness of tertiary education providers in fulfilling their regulatory role in other jurisdictions.

Chapter 14 moves the focus from educational to ALMP internships. Irene Nikoloudakis presents a study of the uneven way in which these arrangements are regulated by seven countries: Argentina, Australia, Canada, China, Germany, South Africa and the USA. She questions the frequent choice to exclude ALMP interns from labour or social protections and calls for greater regulation to ensure they deliver useful training and skill development.

In Chapter 15, Amir Paz-Fuchs explores the commonalities between internships and other 'workfare' schemes which require social security claimants to perform work in order to earn or retain access to government benefits. Concentrating on the UK and the USA, he shows how the justifications for excluding workers involved from the minimum wage and other employment protections are not just similar, but mutually reinforcing. Both types of arrangement highlight a growing trend, which he argues needs to be challenged, towards the legitimacy of providing businesses with free labour.

In Chapter 16, Alexandre de le Court compares the way in which the law of three European countries (Spain, France and Germany) regulates access to 
social security by interns or trainees. His analysis considers not only the more obvious risks, such as those relating to work health and safety, but also those that might be considered less obvious or important for young people, such as unemployment protection and pension rights. Although observing a promising trend in all three countries to greater protection of interns in social security systems, he also notes that some regulatory segmentation - whether relating to formal education or training, the purpose of the contractual arrangements, or the existence of payment to the interns or trainees - continues to detract from the recognition of social security as a right. Given that encouraging traineeships was a primary policy strategy of Europe's 'Youth Guarantee' after the Global Financial Crisis a decade ago, ${ }^{22}$ the chapter is a salutary reminder of steps that need to be taken to protect young people against systemic discrimination in any recovery from economic recession.

Part $\mathrm{V}$ examines internships from the perspective of defending human rights and promoting equal opportunity in the world of work. In Chapter 17, Annika Rosin explores whether the European Union Charter of Fundamental Rights can be used to improve the protection of trainees in the EU by broadening the scope of national labour laws or EU labour directives, or by creating new labour rights directly applicable to trainees. Rosin concludes that the limitations to the application of the charter, as well as the restrictive interpretation of its provisions, reduce its ability to improve the rights of trainees. However, it remains a useful tool for the Court of Justice of the EU to broaden the personal scope of secondary EU legislation, and to contest national limitations to the application of fundamental labour rights.

In Chapter 18, Alysia Blackham considers the extent to which unpaid work experience is likely to be covered by equality law. The chapter identifies the potential relevance of equality law to work experience and canvasses the scope of equality law in Australia and the UK, and the extent to which it might protect or exclude those undertaking work experience in various forms. This analysis is timely, as equality laws are likely to have particular significance for those undertaking work experience and other forms of unpaid labour. However, Blackham concludes that, although it is likely that those engaged in unpaid work experience receive some protection from equality laws in each jurisdiction, the complexity of this legal coverage makes enforcement particularly challenging. As a consequence, those participating in unpaid work experience are unlikely to be able to access their (potential) rights without costly legal assistance - which is problematic given the unpaid nature of the work in which they are engaged.

22 Council Recommendation of 22 April 2013 on Establishing a Youth Guarantee [2013] OJ C120/1. 
Julia López López examines in Chapter 19 the consequences of normalizing unpaid and low-paid work experience opportunities for young people in Spain. She argues that creating and normalizing legal opportunities for unpaid traineeships and poorly paid apprenticeships creates a dynamic of cheap labour which predominantly affects the young in the labour force. With many young people in Spain becoming trapped in a series of precarious work arrangements, López López argues that the Spanish labour laws are creating systemic age discrimination that affects the growing numbers of young people who are struggling to enter the labour market.

Finally, Part VI looks at how the regulation of internships might develop in the future. In Chapter 20 we assess the current impact and possible evolution of international or regional labour standards, briefly review the different types of state regulation found around the world, and examine the role that non-state regulators can and do play. We then conclude by outlining some principles that can usefully guide the regulation of internships and help respond to the policy challenges so thoughtfully and effectively explored throughout this volume.

\subsection{COVID-19 AND THE FUTURE OF INTERNSHIPS}

In 2012, the ILO drew attention to the importance of both promoting internships as a means of moving from education to work and regulating these arrangements to ensure they do not become a means of exploiting desperate young job seekers. These views were expressed in a resolution of the International Labour Conference, which painted a grim picture of the impact of the 2008-09 global financial and economic crisis on youth employment around the world and the long-lasting effects this situation was likely to have unless drastic action was taken. ${ }^{23}$ Since then, the ILO's focus on the role and regulation of internships has continued to be grounded in its concerns to address the youth employment challenge. ${ }^{24}$ The EU's 2014 adoption of a Quality Framework for Traineeships was likewise closely linked to various initiatives designed to address persistently high youth unemployment rates..$^{25}$

A decade on, the world is facing a new economic crisis, brought on by the COVID-19 pandemic and the restrictions imposed to curtail its spread. The ILO's analysis suggests that young people have been even more disproportion-

23 ILO, 'The Youth Employment Crisis' (n 19).

24 See eg Ana Jeannet-Milanovic, Niall O’Higgins and Annika Rosin, 'Contractual Arrangements for Young Workers' in Niall O'Higgins (ed), Rising to the Youth Employment Challenge: New Evidence on Key Policy Issues (International Labour Office 2017).

25 Council of the EU (n 17); and see eg Council Recommendation of 26 April 2013 on Establishing a Youth Guarantee [2013] OJ C120/1. 
ately affected this time around. To the general susceptibility of youth employment to economic downturns must now be added at least three further factors that are making things worse for young people: (1) disruptions to education and training as a consequence of lockdown measures; (2) the concentration of young workers in economic sectors which have been particularly hard-hit by the economic effects of the COVID-19 pandemic and accompanying lockdown measures; and (3) the increasing concentration of young people in less protected forms of employment. ${ }^{26}$ As a consequence, it is possible we may see a 'lockdown generation' who will be 'scarred throughout their working lives'. ${ }^{27}$

In the early stages of the pandemic, and as a number of surveys have revealed, many internship programmes were halted or cancelled..$^{28}$ In both India and the Philippines, for example, three-quarters of all internships were 'completely interrupted' ${ }^{29}$ However, a number of arrangements continued on a 'virtual' basis, with interns working remotely and interacting with their supervisors (if at all) online. In the USA, for example, nearly 46 per cent of employers surveyed by the National Association of Colleges and Employers had taken that step. ${ }^{30}$ A different survey specifically asked college students about being offered remote internships. While just over half were grateful for

26 ILO, 'Preventing Exclusion from the Labour Market: Tackling the COVID-19 Youth Employment Crisis' (ILO Policy Brief, 27 May 2020), https://www.ilo.org/ wcmsp5/groups/public/---ed_emp/documents/publication/wcms_746031.pdf, accessed 30 March 2021.

27 ILO, ILO Monitor: COVID-19 and the World of Work (4th edn, ILO 2020) 2, https://www.ilo.org/wcmsp5/groups/public/---dgreports/---dcomm/documents/brief ingnote/wcms_745963.pdf, accessed 30 March 2021.

28 Besides those mentioned below, see eg Fair Internship Initiative, 'Impact of Covid-19-related Measures on UN Internships' (1 May 2020), https://fairinternship initiative.org/2020/05/01/impact-of-covid-19-related-measures-on-un-internships/, accessed 30 March 2021; Cartus, 'COVID-19 Impact on Internships: Pulse Survey' (10 June 2020), https://www.cartus.com/files/4315/9172/6562/Cartus-Internship_Pulse -Survey-0520.pdf, accessed 30 March 2021; CareerUp, 'Remote Internship Statistics: A COVID-19 Impact Report' (Remote Internships, 2020), https://remoteinternships .com/remote-internship-statistics/, accessed 30 March 2021; Glassdoor Economic Research, 'U.S. Internship Hiring Cut in Half Since COVID-19 Crisis' Glassdoor (28 April 2020), https://www.glassdoor.com/research/internship-hiring-coronavirus/, accessed 30 March 2021.

29 ILO and Asian Development Bank, Tackling the COVID-19 Youth Employment Crisis in Asia and the Pacific (ILO Regional Office for Asia and the Pacific and Asian Development Bank 2020) 17.

30 National Association of Colleges and Employers, 'Quick Poll: Employers Maintaining Plans for College Hiring, Holding Internships' (5 May 2020), https:// www.naceweb.org/talent-acquisition/trends-and-predictions/quick-poll-employers -maintaining-plans-for-college-hiring-holding-internships/, accessed 30 March 2021. 
the opportunity to be able to work from home, 43 per cent expressed concerns that the experience would not be as good, that they would not be able to prove they deserved a full-time role at the organization, or that they would not meet new contacts in person. ${ }^{31}$ Even before the coronavirus, some firms had started offering the opportunity to gain experience in this way. ${ }^{32}$ Other internship brokers, unsurprisingly, are now reorienting their businesses in this direction. ${ }^{33}$

In the longer term, it seems likely that many policy-makers will see a role for work-based learning as part of the 'urgent, large-scale and targeted employment policy responses' that the ILO suggests are 'needed to prevent lost opportunities and greater youth exclusion'. ${ }^{34}$ Some countries have already started down this path. In April 2020, the Canadian government announced that it would provide funding to support up to 20000 post-secondary students to obtain paid work experience related to their field of study. ${ }^{35}$ In Singapore, a government bailout package has assisted the National University of Singapore and the Nanyang Technological University to offer paid traineeships. ${ }^{36}$ However, if social distancing and travel restrictions remain in place for an extended period some, or perhaps most, of these arrangements will need to be implemented virtually.

It is possible that some of the variations to working patterns established during the COVID-19 lockdowns may result in lasting changes to internships, together with many other features of the labour market. The ILO has highlighted the possibility for "virtual work-based learning opportunities [to] help young people to gain valuable work experience even if movement restrictions are in place'. ${ }^{37}$ However, it is also important that measures are taken to ensure the necessary access to the information and communication technologies needed to support access to online forms of work-based learning. Otherwise,

31 Yello, 'Virtual Internship Statistics and Trends: A 2020 COVID-19 Impact Report' (2020), https://yello.co/blog/virtual-internship-statistics/, accessed 30 March 2021.

32 See eg Virtual Internships, https://www.virtualinternships.com/, accessed 30 March 2021.

33 See eg Australian Internships, 'Virtual Internship Program', https://www .internships.com.au/virtual-internship, accessed 30 March 2021.

34 ILO, 'Preventing Exclusion' (n 26) 14.

35 Department of Finance Canada, 'Support for Students and Recent Graduates Impacted by COVID-19' (Government of Canada, 22 April 2020), https://www.canada .ca/en/department-finance/news/2020/04/support-for-students-and-recent-graduates -impacted-by-covid-19.html, accessed 30 March 2021.

36 Yojana Sharma, 'University Jobs and Traineeships for Coronavirus Cohort' University World News (28 April 2020), https://www.universityworldnews.com/post .php?story $=20200428090338765$, accessed 30 March 2021.

37 ILO, 'Preventing Exclusion' (n 26) 15. 
this shift may 'exacerbate existing inequalities for those who already face disadvantages in trying to access and engage in learning', ${ }^{38}$

More generally, the prospect of online internships becoming a new (but unpaid) form of 'gig work', facilitated through digital labour platforms, is more than a little concerning. ${ }^{39}$ If nothing else, it underscores the importance of understanding how and why internships have come to play the role that they do, and of thinking how they might be sensibly regulated. That is what the chapters in this volume seek to achieve - and why this volume represents such an important and novel contribution to the literature on labour-market policy and regulation.

38 Paul Comyn, 'Learning in the Times of COVID-19: Can Distance Learning Become the New Normal?' (ILO Skills and Employability Branch, 3 May 2020), https://www.ilo.org/skills/Whatsnew/WCMS 743434/lang--en/index.htm, accessed 30 March 2021. As to other issues that may need to be addressed to ensure the quality of virtual internships, see eg Center for Research on College-Workforce Transitions, UW-Madison, What to Do about Internships in Light of the COVID-19 Pandemic? A Short Guide to Online Internships for Colleges, Students, and Employers (UW-Madison 2020), http://ccwt.wceruw.org/documents/CCWT_report_COVID-19 \%20Internships.pdf, accessed 30 March 2021.

39 For recent assessments of the scope and regulation of digital platform work, see eg Zachary Kilhoffer, Willem Pieter De Groen, Karolien Lenaerts, Ine Smits, Harald Hauben, Willem Waeyaert and others, Study to Gather Evidence on the Working Conditions of Platform Workers (VT/2018/032, Final Report, Publications Office of the European Union 2020); Paula McDonald, Penny Williams, Andrew Stewart, Robyn Mayes, Damian Oliver, Digital Platform Work in Australia: Prevalence, Nature and Impact (Victorian Department of Premier and Cabinet 2020), https://s3.ap-southeast-2 .amazonaws.com/hdp.au.prod.app.vic-engage.files/7315/9254/1260/Digital_Platform _Work_in_Australia_-_Prevalence_Nature_and_Impact_-_November_2019.pdf, $\overline{\operatorname{accessed}} 3 \overline{0}$ March $20 \overline{2} 1$. 